\title{
THE IMPACT OF PROCEDURAL FAIRNESS AND INTERPERSONAL TRUST ON BUDGETING WORK PRESSURES (AT THE REGIONAL FINANCIAL AND ASSET MANAGEMENT REVENUE AGENCY ON THE ISLAND OF JAVA)
}

\author{
Lilis Sulistyani ${ }^{1} \square$, Ifah Lathifah $2 \square$, Eko Madyo Sutanto ${ }^{3} \square$, Ika Swasti Putri $4 \square$ \\ 1,2 Master of Management Lecturer in STIE AUB Surakarta, Central Java \\ ${ }^{3}$ Lecturer in Accounting FEB USB Surakarta, Central Java \\ ${ }^{4}$ Accounting Lecturer in STIE AUB Surakarta, Central Java
}

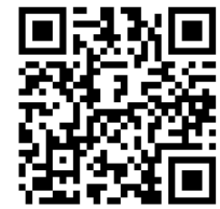

Received 01 October 2021

Accepted 15 October 2021

Published 30 November 2021

\section{CorrespondingAuthor}

Lilis Sulistyani,

lilissulistyani44@yahoo.co.id

DOI 10.29121/ijetmr.v8.i11.2021.1056

Funding: This research received no specific grant from any funding agency in the public, commercial, or not-for-profit sectors.

Copyright: (C) 2021 The Author(s). This is an open access article distributed under the terms of the Creative Commons Attribution License, which permits unrestricted use, distribution, and reproduction in any medium, provided the original author and source are credited.

\section{ABSTRACT}

This research empirically investigates the sustainability of the effect of budget participation on the work pressures of the Regional Revenue, Financial and Asset Management Agency (BPPKAD) in Java Island. The Revenue Budget on BPPKAD is very likely to cause work pressure for the agency head or the concerned service employee. The population of this study is an employee of the Regional Revenue, Financial and Asset Management Agency (BPPKAD) in Java Island. Sampling using random sampling techniques. Data collected as many as 60 respondents and tested was conducted with a partial least square structural equation model (PLS-SEM) in the form of the warps 3.0 program. The test results proved that budget participation had a causal relationship on procedural fairness and interpersonal trust. Procedural fairness has a significant impact on interpersonal trust and work pressures. Interpersonal trust has a substantial impact on work pressures.

Keywords: Budget Participation, Procedural Justice, Interpersonal Trusts, and Work Pressures

\section{INTRODUTION}

In Indonesia, in the era of democratization and regional autonomy in recent years, it has widely allowed the involvement of employees in organizational decision-making processes such as budgeting. The preparation of the budget in participation enables the exchange of information between superiors and subordinates at the same management level.

The public budget describes the financial condition of an organization, including revenue, spending, and activity. The budget is accountability instrument for managing comunity funds and implementition of programs financed with public money (Mardiasmo, 2002: 61). The process of preparing a budget thus needs to involve various components of the work unit in the organization.

In Indonesia, during the 2000 era of government, did budgeting was done with a top-down system. The budget plan and amount have been set by the boss or budgetary power holder so that the budget implementer only does what has been prepared by the superior (Omposunggu and Bawono, 2006). If the preparation of a budget based on the will of the superior without 
involving the participation of subordinates can cause difficulties for associates to achieve it. Conversely, suppose the budget preparation by choice of aides can also cause subordinates' low motivation to achieve the optimal target. In that case,s, the involvement of subsidiaries in the budget preparation will significantly allow them to provide local information that is known.

Research - Research on the impact of workplace program participation on managerial attitudes and behaviors (Greenberg and Folger (1983); Kren and Liao, 1988). Some previous studies have shown that the behavioral impact of involvement of budgeting are far more complex than previously thought. Some studies have shown that the positive impact of involvement may depend upon several moderation variables (Brownell, 1982; Lindquist, 1995; Libby, 1999). Another research that reveals the complexity of the processes by which involvement influences managerial actions and behavior (Chenhall and Brownell, 1988; Kren (1992); Nouri and Parker, 1998; Lau and Buckland, 2001). Other research investigated the same using information-related variables (Kren (1992)), budget completeness and organizational aspects (Nouri and Parker, 1998).

Lau and Buckland (2001) suggest that interpersonal trustare often an important intermediate factor that influences the connection among budget participation and work pressures. However, Lau and Buckland's (2001) study shows that the consequences of interpersonal trust mediation are only partial. this suggests that the link between employee engagement and work tension (and possibly other triggering factors) is way quite expected and other important intervention elements are under-accounted for like procedural fairness or interpersonal trust.

Lau and Tan's study (2006) draws on the general theory of organizational justice and procedural justice theory, particularly, explaining the connection between budget participation and therefore and the pressure of work. There are two forms of organizational justice: distributive justice and procedural justice. Distributive justice deals with the goals achieved or the content of justice. In contrast, procedural justice is related to the means used to accomplish the justice process within the organization.

Management accounting studies like Lindquist (1995); Magner et al. (1995); Libby, (1999); Wentzel (2002) pays increasing attention to procedural justice and has found this sort of fairness to be important in explaining the connection between accounting control systems and subordinate behavior. supported some previous research, procedural fairness as an explanatory variable between budget participation and employee behavior appears to be negligible.

This research will examine the effect of budget participation on the pressures (tensions) of work mediated by procedural fairness and interpersonal trust. This research model will try to investigate the establishment of the relationship of budget participation with job pressures (tensions). The Regional Revenue Office or which has now been renamed based on Government Regulation No. 38 of 2007 on the Division of Government Affairs between the Government, Provincial Government, and District / City Government and Government Regulation No. 41 of 2007 on Regional Device Organization, then since 2009 the Organization of Revenue Agency, Financial Manager and Regional Assets or (BPPKAD) as the object of research tian. The underlying consideration is that the Agency or The Agency becomes the backbone of local government in shoring up local revenues to fund local government expenditures. Revenue Budget at the Revenue Agency, Financial Manager and 
Regional Assets or (BPPKAD), is very likely to cause work pressure for the head of the Agency / Agency or also employees in the relevant office.

\section{LIBRARY AND HYPOTHESIS REVIEW}

\subsection{BUDGET PARTICIPATION}

Garrison et al. (2013) define budget participation as a budget prepared with all employees or managers' cooperation and full participation at various levels. According to Hansen and Mowen (2013), Budget participation may be a budgeting approach that permits managers liable for the budget performance to participate in budget development. Budget participation communicates the sense of responsibility of lower-level managers and encourages creativity.

\subsection{PROCEDURAL JUSTICE}

Can conceptualize procedural justice as assessing the fairness of social norms relating to decision-making taken and how authorities and others treat a person (Lind \&Tyler, 1988). Procedural justice is that the perceived justice of the means and procedures wont to determine the employee's amount of reward or compensation (Folger \& Konovsky, 1989).This justice covers all aspects of the organization as a way for leaders to assess employee performance, inform performance results, and set rewards for employees in the form of bonuses or promotions. Thibaut and Walker $(1975,1978)$ argue that the concept of procedural justice relates to legal arrangements relating to the effect of "control" in dispute resolution.

\subsection{INTERPERSONAL TRUST}

Deutsch (1960) mentions that interpersonal trust has two components: the belief in the ability and intention to relate. Mayer (1995) and Rousseau (1998) argue that interpersonal beliefs are psychological states that consist of the choice to accept vulnerability to the actions of others based on the expectation that the other will perform specific actions, regardless of the ability to monitor or control the other party. According to Wang (2009) that trusts built by related parties are called interpersonal beliefs. Pearson and Raeke (2000) and Hall et al. (2001) state interpersonal trust as a trust created through repetition of interactions, which will test expectations about the behavior of trusted people over time. This source of interpersonal trust is from an individual's experience and personality.

\subsection{WORK PRESSURE}

The definition of work pressure (Job tension) is also as job stress from Spurgeon (2008) stated as "... Stress results from an imbalance between the demands of the individual and his or her ability to meet those demands". Demands that exceed the ability to cause stressful situations within the individual, the control or control of the boss at the workplace causes work pressure.

Robbins (2007: 793) suggests that stress is a dynamic condition in which the individual faces the opportunity of obstacles related to what he wants. Then the results are perceived as uncertain but essential. Work stress, also known as work 
pressure, is a condition of dependence that affects emotions and thought processes. Hasibuan $(2009 ; 201)$ adds that people who experience stress will become nervous and feel chronic conditions.

\subsection{HYPOTHESIS}

Based on theoretical studies, previous research formulated the following hypotheses:

1) The Effect of Budget Participation on Procedural Justice

Procedural fairness will be challenging to realize as long as budget participation does not guarantee that managers will receive the desired budget due to scarce resource arrangements and employees do not improve the understanding of budget distribution managers (Greenberg, 1993). Libby (1999) asserts that budget allocation is essential during a consultative budgeting environment in which individuals who do so cannot influence budget goals. In addition, when individuals participate in the budget process, they gain control over the budget process. There is a direct link between the rule of budget processes and perceptions of procedural fairness demonstrated by Lind and Tyler (198); Thibaut and Walker 1975). Libby (1999), Wentzel (2002), and Lau Tan (2006) found that positive participation was related to perceived procedural fairness. Based on this description, hypothesis 1 :

$\mathrm{H}_{1}$ : Budget Participation has a significant effect on Procedural Justice.

2) The Effect of Budget Participation on Interpersonal Trusts.

The budget participation process provides the exchange of information between the boss/budgetary power holder and the subordinate/executor of the budget. The budgeting process that meets these criteria allows getting a good reaction from employees/subordinates, which means that the budget participation process will gain the trust of employees/subordinates. Lau and Buckland Research (2001); Lau Tan (2006) showed that participation is positively associated with confidence. Based on this description, hypothesis 2 :

$\mathrm{H}_{2}$ : Budget participation has a significant effect on interpersonal trust.

\section{3) The Effect of Procedural Justice on Interpersonal Trusts}

Work evaluation procedures are supposedly excellent and fair if they are by the fairness of the regulations applied. Strategies that fit these criteria make it possible to get a good reaction from employees. As a result, superiors who carry out fair procedures will gain the trust of subordinates. Research Lau and Sholihin (2005), Lau and Tan (2006), Lau et., al. (2008), Hartmann and Slapnicar (2009) found that procedural fairness significantly positively affected trust. Based on this description, hypothesis 3:

$\mathrm{H}_{3}$ : Procedural Justice has a significant effect on Interpersonal Trust.

4) The Effect of Procedural Justice on Work Pressures.

When individuals perceive that decisions stem from a fair process, they will commit to the goal. Members of the organization believe that the results of decisions 
stem from the principle of justice. This condition will be able to prevent employees from work pressure. For example, Earley and Lind (1987) found a significant pathway between the two, where procedural fairness significantly affected an employee's work stress. Based on this description, hypothesis 4:

$\mathrm{H}_{4}$ : Procedural Justice has a significant effect on work pressures.

5) The Effect of Interpersonal Trust on Work Pressure.

Johnson and Johnson (2009) argue that trust is the belief that others will do their best so that there is an attitude of acceptance, support, sharing, and cooperation. Trust also includes consistent, honest and trustworthy behavior that a person exhibits. When employees trust the boss in the budgeting process, this can reduce work tensions/ pressures. Previous studies (Hopwood, 1972; Otley, 1978; Ross, 1994) have shown that budget participation can affect employee work tensions through intervention variables such as interpersonal trust among subordinates and superiors Based on this description, hypothesis 5:

$\mathrm{H}_{5}$ : Interpersonal trust has a significant effect on work pressure.

\section{METHOD}

Employees of the Regional Financial and Asset Management Revenue Agency (BPPKAD) in Java Island are defined as the population. The sample of this study is employees of the Regional Revenue, Financial, and Asset Management Agency (BPPKAD) on the island of Java. They are involved or participate in the preparation of the budget. The withdrawal of this study sample is random sampling. As many as 60 respondents obtained data.

Budget participation was measurable by 6 questionnaires on a 5-point Likert scale. Procedural fairness was measurable by 6 questionnaires on the 5-point Likert scale, 5 questionnaires measured interpersonal trust on a 5-point Likert scale, and work pressure was measurable by 9 questionnaires on the 5-point Likert scale. Referring to Hair et al., (2011) and Kock (2011) hypothesis testing using SEM-PLS with warps version 3.00 program.

\section{RESULTS AND DISCUSSIONS}

\subsection{RESULTS}

\section{Validity and Reliability Test (Second Stage)}

1) Validity Test

Loading factors and average variance extracted (AVE) show convergent validity. In running 1 (first) for indicators of interpersonal trust variables (IT), namely IT6, procedural justice variables (PJ), namely PJ2 and PJ5, and work pressure variables (WP), namely WP5 and WP6, have loading factor values below 0.70 as required. IT6 loading factor value of 0.648 ; PJ2 of 0.683 ; PJ 5 of 0.276 ; WP5 of 0.254; and WP6 is 0.400 . These indicators on the 2 nd running remove from the model. In the 2 nd running obtained, the loading factor results of each construct indicator are declared valid with a loading factor value of $>0.7$ (Appendix 1).

Average variance extracted (AVE) values use for the evaluation of convergent validity, with criteria having to be $>0.50$ (Fornell and Lacker, 1981). The second 
running result is presented in Table 1 , indicating that all the variables studied are already qualified as specified because all AVE values of each variable are $>0.50$.

Table 1 Average Variance Extracted /AVE (Running 2 - output WarpPls 3.0 )

$\begin{array}{lc}\text { Variable } & \text { Average Variance Extracted } \\ \text { Budget participation (BP) } & 0,660 \\ \text { Procedural Justice (PJ) } & 0,581 \\ \text { Interpersonal Trust (IT) } & 0,682 \\ \text { Work Pressure (WP) } & 0,583\end{array}$

The results of the discriminant validity test are visible from the results of the square root of $\mathrm{AVE}$ and the correlation between latent constructs. Table 2 presents the real root value of AVE and the correlation between latent constructs for the second run, showing the correlation values between latent constructs for all variables showing values smaller than the square root values of AVE. It can be concluded that all constructs have met discriminant validity because they have an average variance extracted > correlation between constructs (Kock, 2012); Ghozali and Latan, 2012).

\begin{tabular}{ccccc|}
\hline \multicolumn{4}{c}{ Table 2 Discriminant validity test (output WarpPls 3.0) } \\
\hline Variable & BP & PJ & IT & WP \\
BP & $\mathbf{0 , 8 1 3}$ & 0,731 & 0,680 & 0,660 \\
PJ & 0,731 & $\mathbf{0 , 8 2 6}$ & 0,747 & 0,767 \\
IT & 0,680 & 0,747 & $\mathbf{0 , 8 0 2}$ & 0,762 \\
WP & 0,660 & 0,767 & 0,762 & $\mathbf{0 , 8 3 5}$ \\
\hline
\end{tabular}

\section{2) Reliability Test}

Construct reliability are visible from composite reliability and cronbach's alpha Cronbach's alpha values. Table 3 presents composite reliability and cronbach's alpha values of each construct for the second run, showing the cronbach's alpha coefficient and composite reliability values for all variables studied already qualified $>0.70$, meaning all variables studied are reliable.

\begin{tabular}{|c|c|c|}
\hline Variable & composite reliability coefficient & cronbach's alpha coefficient \\
\hline Budget participation (BP) & 0,907 & 0,871 \\
\hline Procedural Justice (PJ) & 0,847 & 0,759 \\
\hline Interpersonal Trust (IT) & 0,914 & 0,883 \\
\hline Work Pressure (WP) & 0,907 & 0,881 \\
\hline
\end{tabular}

\section{Full Structural Model Testing}

Structural model output - full model presented in Figure 1. Table 4 shows the path coefficient and the $\mathrm{p}$ values as follows:

1) The BP $\rightarrow$ PJ line shows a coefficient value of 0.741 with a value of $\mathrm{P}<0.001$.

2) The BP $\rightarrow$ IT line shows a coefficient value of 0.330 with a value of $\mathrm{P}<0.001$ 
3) The IT $\rightarrow$ WP line shows a coefficient value of 0.350 with a value of $\mathrm{P}=0.007$.

4) The PJ $\rightarrow$ IT line shows a coefficient value of 0.590 with a value of $\mathrm{P}<0.001$.

5) The $\mathrm{PJ} \rightarrow$ WP line shows a coefficient value of 0.530 with a value of $\mathrm{P}<0.001$.

Figure 1

Structural Model Output - Full Model

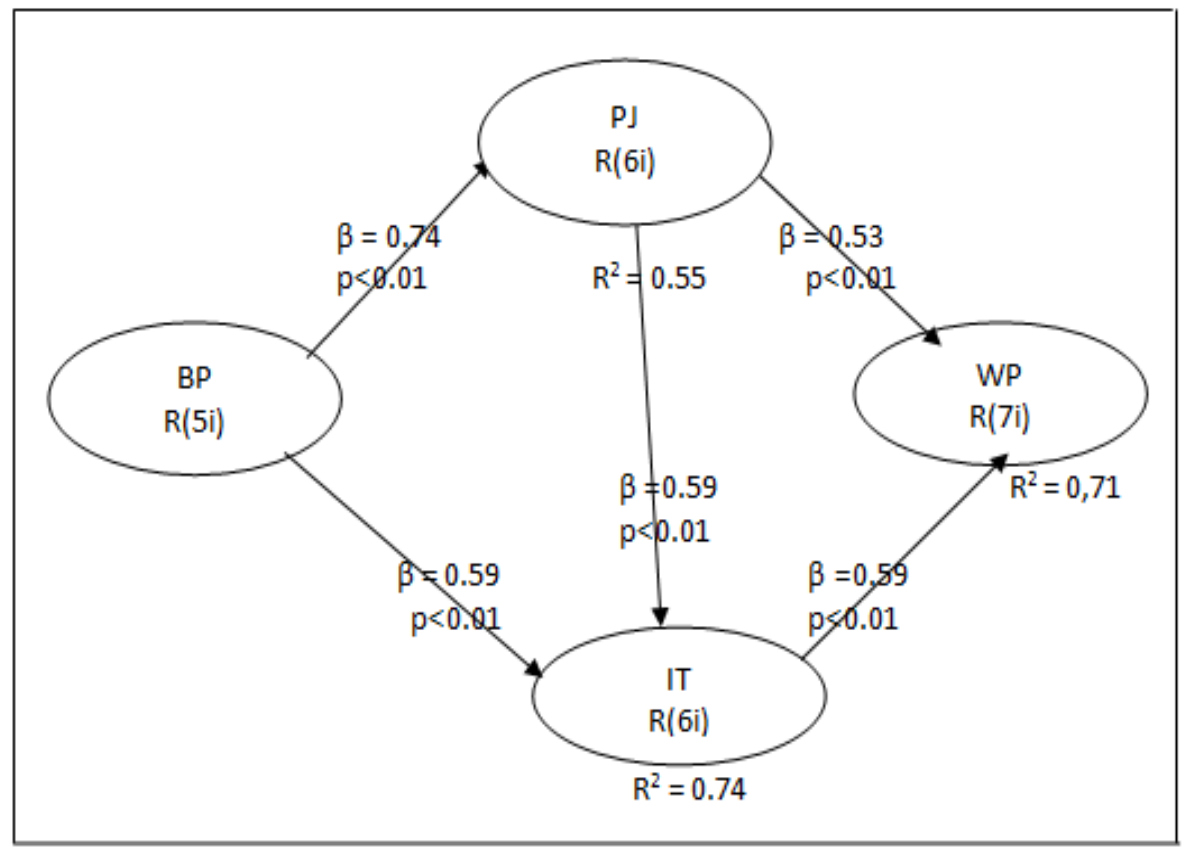

Figure 1

Table 4 presents the results of the model fit index and p-values, namely the three fit model indices consisting of the average path coefficient (APC), the R-Squared average (ARS) and the average variance inflation factor (AVIF). The model is declared fit if the p-value of APC and ARS $<0.05$ and AVIF $>5$ (Kock, 2012). Based on Table 4, the goodness of fit model has been fulfilled.

Table 4 also presents the f-squared coefficient as an effect measure. As Hock (2013) and Hair et.al (2013) the effect size is a path coefficient from a practical point of view, consisting of 3 types, namely strong with effect size $>0.35$; moderate if the effect size is between 0.15 to 0.35 and weak if the effect size is 0.02 to 0.15 . 


\section{Table 4}

Table 4

Model fit indies, path coefficients and p- value, effect sizes for path coefficient - Full Model

\begin{tabular}{|c|c|c|}
\hline \multirow[t]{3}{*}{ Model fit indices and $p$ values } & \multicolumn{2}{|c|}{$\mathrm{APC}=0,494, \mathrm{p}<0.001$} \\
\hline & \multicolumn{2}{|c|}{ ARS $=0.615, p<0.001$} \\
\hline & \multicolumn{2}{|c|}{ AVIF $=2.090$, Good if $<5$} \\
\hline \multirow[t]{5}{*}{ Path coefficients and $p$ values } & $\mathrm{BP} \rightarrow \mathrm{PJ}$ & $0,741, p<0.001$ \\
\hline & $\mathrm{BP} \rightarrow \mathrm{IT}$ & $0,330, P<0.001$ \\
\hline & $\mathrm{PJ} \rightarrow \mathrm{IT}$ & $0,590, p<0.001$ \\
\hline & $\mathrm{PJ} \rightarrow \mathrm{WP}$ & $0,530, p<0.001$ \\
\hline & $\mathrm{IT} \rightarrow \mathrm{WP}$ & $0,350, p=0,007$ \\
\hline Effect sizes for & \multicolumn{2}{|c|}{$B \mathrm{P} \rightarrow \mathrm{PJ}=0,820(>0,35=$ large $)$} \\
\hline path coefficients & \multicolumn{2}{|c|}{$\mathrm{BP} \rightarrow \mathrm{IT}=0,402(>0,35=$ large $)$} \\
\hline & \multicolumn{2}{|c|}{$\mathrm{PJ} \rightarrow \mathrm{IT}=0,491(>0,35=$ large $)$} \\
\hline & \multicolumn{2}{|c|}{ PJ $\rightarrow W P=0,531(>0,35=$ large $)$} \\
\hline & \multicolumn{2}{|c|}{$\mathrm{II} \rightarrow \mathrm{WP}=0,362(>0,35=$ large $)$} \\
\hline
\end{tabular}

The full collinearity values of VIF, Q-squared and R-squared values are shown in Table 5. If the R-squared value is higher, it means that the explanatory power of predictors of latent variables in the model is getting better. Because R-squared is a measure of endogenous variables, which describes the amount of variance in exogenous variables. R-squared is always positive, while Q-squared may be negative. Expected Q-squared coefficient $>0$ as a measure of predictive validity can be accepted. Full collinearity VIF shows the results of the full collinearity test, both lateral and vertical multicollinearity. As Kock (2013) that the criteria for the full collinearity test $<3.3$.

\section{Table 5}

Table 5

\begin{tabular}{|ccc|}
$\begin{array}{c}\text { R-squared, } \\
\text { Q-squared value and Full collinearity VIF } \\
\text { (Output WarpPls3.0) }\end{array}$ \\
\hline R-squared & Q-squared & Full collinearity VIF \\
\hline IT $=0,670$ & IT $=0,670$ & BP $=1,932$ \\
PJ $=0,463$ & PJ $=0,467$ & IT $=2,269$ \\
WP $=0,713$ & WP $=0,716$ & PJ $=2,331$ \\
& & WP $=2,446$ \\
\hline
\end{tabular}




\subsection{DISCUSSION}

Hypothesis 1 states that budget participation has a significant effect on procedural fairness, supported by this study. Budget participation proved to have a significant positive impact on procedural justice. This result indicates that the involvement of agency employees in the budgeting process will encourage the creation of procedural fairness in the relevant agencies. The results of respondents' answers based on the highest loading factor values (budget participation variables PA5, PA2, and P3) are as follows:

1) The head of the agency always pays attention to the contributions made by the budget team.

2) The frequency of giving advice and opinions on budget proposals is adequate and involves employees setting performance targets.

Based on the respondent's answer, agency employees feel involved in budgeting activities as performance targets. This condition certainly encourages and even proves that the agency where they work has created procedural justice. The results of this study support lind and Tyler's research (198); Thibaut and Walker 1975). Libby (1999), Wentzel (2002), and Lau and Tan (2006) showed that participation is positively associated with interpersonal trust in organizations.

Hypothesis 2 states that Budget Participation has a significant effect on interpersonal trust. Acceptance of hypothesis 2 indicates that the agency's head always pays attention to the budget team's contributions. The frequency of advising and opinions on budget proposals is adequate. It involves employees setting performance targets, which means that when agency employees feel involved in budgeting activities as performance targets, this condition will cause trust from employees/subordinates. Likely, trust between employees in the agency will also be more vital. The results of this study are in line with the results of research from Lind and Tyler (198), Thibaut and Walker (1975), Libby (1999), Wentzel (2002), Lau and Tan (2006) stated that participation is positively related to interpersonal trust in organizations.

Hypothesis 3 states procedural fairness has a significant effect on interpersonal beliefs, supported by this study. Acceptance of hypothesis 3 indicates that superiors who carry out fair procedures will gain the trust of subordinates. When the head of the agency does not violate the norms of professional guidelines in budgeting, employees involved in budgeting can provide input for decision-making, and final budget decisions are made based on accurate information. Can increase employee confidence in superiors. The findings of this study are in line with the research of Lau and Sholihin (2005), Lau and Tan (2006), Lau et al. (2008) as well as Hartman and Slapnicar research (2009), which found that procedural fairness positively affects trust.

Hypothesis 4 states procedural fairness has a significant effect on work pressures, evidenced in this study. Acceptance of hypothesis 4 indicates that when the head of the agency does not violate the norms of professional guidelines in budgeting, employees involved in budgeting can provide input for decision making, and final budget decisions are made based on accurate information. Can increase work pressure for employees. The underlying reason if traced from the employee's response to the questionnaire because the employee feels the workload or responsibility or work time becomes excessive or too heavy. The employee feels chased by time at work. So fair treatment by the agency's head turns out that it 
causes stress in position for some employees. The results support Earley and Lind's (1987) research which found that procedural fairness significantly affects the focus of employee work.

Hypothesis 5 states interpersonal trust has a significant effect on work pressures evidenced in this study. Acceptance of hypothesis 5 indicates that although agency employees believe that the head of the agency has acted reasonably and responsibly, performs duties consistently, has an openness and morals on the accuracy of information communicated politely and appropriately, it increases work pressure for employees. If traced from the employee's response to the questionnaire, the underlying reason is that employees feel the workload or responsibility or work time becomes excessive or too heavy. Employees feel chased time at work. The results of this study support Hopwood's view (1972), Otley (1978), and Ross (1994). Interpersonal trusts can influence work pressure.

\section{CONCLUSIONS AND SUGGESTIONS}

Hypothesis 1 is supported or accepted. These results indicate that when individuals participate in the budget process, they gain control over the budget process and procedural fairness of the agency. Hypothesis 2 is supported or accepted. These results indicate that the budget participation process gained the trust of agency employees. Hypothesis 3 is supported or accepted. Acceptance of hypothesis 3 means that fair procedures certainly gain the confidence of subordinates. Hypothesis 4 is supported or accepted. These results suggest that procedural fairness significantly affects agency employees in the face of work stress. Hypothesis 5 is supported or accepted. These results indicate that employee trust in the superior in the budgeting process affects the employee's work pressures.

Advice for future researchers is related to selection and sampling with techniques by the research objectives, such as purposive sampling techniques. Other researchers need to consider using the number of indicators in each construct to hope that the natural conditions in the field obtain the results.

\begin{tabular}{|lcl|}
\hline \multicolumn{2}{c|}{ Appendix 1 Loading factor IndiCator Construct (Running 2) } \\
\hline \multicolumn{1}{|c}{ Indicator } & Loading & \\
\hline BP1 & 0,775 & Valid \\
\hline BP2 & 0,818 & Valid \\
\hline BP3 & 0,794 & Valid \\
BP4 & 0,803 & Valid \\
\hline BP5 & 0,869 & Valid \\
\hline PJ1 & 0,711 & Valid \\
\hline PJ3 & 0,772 & Valid \\
\hline PJ4 & 0,774 & Valid \\
\hline PJ6 & 0,790 & Valid \\
\hline IT1 & 0,776 & Valid \\
\hline IT2 & 0,836 & Valid \\
\hline IT3 & 0,848 & Valid \\
\hline IT4 & 0,830 & Valid \\
\hline IT5 & 0,836 & Valid \\
\hline WP1 & 0,785 & Valid \\
\hline WP2 & 0,756 & Valid \\
\hline WP3 & 0,748 & Valid \\
\hline
\end{tabular}




\begin{tabular}{lll} 
WP4 & 0,766 & Valid \\
WP7 & 0,803 & Valid \\
WP8 & 0,724 & Valid \\
WP9 & 0,761 & Valid \\
\hline
\end{tabular}

\section{REFERENCES}

A. J. R. Nauw, S. M. Fatem, S. B. Husodo, and M. Sagrim (2016), "Pemanfaatan tumbuhan cempedak (Artocarpus champeden) oleh masyarakat Kampung Sabun Distrik Aitinyo Tengah Kabupaten Maybrat, Papua Barat," J. Ilmu Kehutan., vol. 10, no. 1, pp. 46-56. Retrieved from https://doi.org/10.22146/jik.12631

D. Mardiasmo, P. H. Barnes, and Y. Sakurai (2008), "Implementation of good governance by regional governments in Indonesia: the challenges,".

D. Rousseau (1995), Psychological contracts in organizations: Understanding written and unwritten agreements. Sage publications. Retrieved from https://doi.org/10.4135/9781452231594

D. W. Johnson and R. T. Johnson (2009), "An educational psychology success story: Social interdependence theory and cooperative learning," Educ. Res., vol. 38, no. 5, pp. 365-379. Retrieved from https://doi.org/10.3102/0013189X09339057

Deutsch (1979), "Relation between Procedural and Distributive Justice, The," Va. L. Rev., vol. 65, p. 1401. Retrieved from https://doi.org/10.2307/1072580

F. Hartmann and S. Slapničar (2009), "How formal performance evaluation affects trust between superior and subordinate managers," Accounting, Organ. Soc., vol. 34, no. 6-7, pp. 722-737. Retrieved from https://doi.org/10.1016/j.aos.2008.11.004

H. and Mowen (2013), "Performance-based risk-sharing arrangements-good practices for design, implementation, and evaluation: report of the ISPOR good practices for performance-based risk-sharing arrangements task force," Value Heal., vol. 16, no. 5, pp. 703-719. Retrieved from https://doi.org/10.1016/j.jval.2013.04.011

I. Laish, M. Braun, E. Mor, J. Sulkes, Y. Harif, and Z. Ben Ari (2011), "Metabolic syndrome in liver transplant recipients: prevalence, risk factors, and association with cardiovascular events," Liver Transplant., vol. 17, no. 1, pp. 15-22. Retrieved from https://doi.org/10.1002/lt.22198

I. Lathifah and A. Rohman (2014), "The Influence of Work-family conflict on Turnover intentions with Job satisfaction as an Intervening Variable on Public Accountant Firms in Indonesia,". Retrieved from https://doi.org/10.17722/ijrbt.v5i2.342

I. Lathifah (2020), "No Title No Title No Title," Pap. Knowl. . Towar. a Media Hist. Doc., pp. 12-26.

I. Ulum, I. Ghozali, and A. Chariri (2008), "Intellectual capital dan kinerja keuangan perusahaan; Suatu analisis dengan pendekatan Partial Least Squares (PLS),". 
J. Greenberg and R. Folger (1983), "Procedural justice, participation, and the fair process effect in groups and organizations," in Basic group processes, Springer, pp. 235-256. Retrieved from https://doi.org/10.1007/978-14612-5578-9_10

J. H. Christensen et al. (2013), "Climate phenomena and their relevance for future regional climate change," in Climate change 2013 the physical science basis: Working group I contribution to the fifth assessment report of the intergovernmental panel on climate change, Cambridge University Press, pp. 1217-1308.

J. M. Spurgeon, H. A. Atwater, and N. S. Lewis (2008), "A comparison between the behavior of nanorod array and planar Cd (Se, Te) photoelectrodes," J. Phys. Chem. C, vol. 112, no. 15, pp. 6186-6193. Retrieved from https://doi.org/10.1021/jp077481u

J. Mao, D. D. Price, and D. J. Mayer (1995), "Mechanisms of hyperalgesian and morphine tolerance: a current view of their possible interactions," Pain, vol. 62, no. 3, pp. 259-274. Retrieved from https://doi.org/10.1016/03043959(95)00073-2

K. B. Ompusunggu and I. R. Bawono (2006), "Pengaruh Partisipasi Anggaran Dan Job Relevant Information (JRI) Terhadap Informasi Asimetris (Studi pada Badan Layanan Umum Universitas Negeri di Kota Purwokerto Jawa Tengah)," J. Simp. Nas., vol. 9.

K. Wentzel (2002), "The influence of fairness perceptions and goal commitment on managers' performance in a budget setting," Behav. Res. Account., vol. 14, no. 1 1, pp. 247-271. Retrieved from https://doi.org/10.2308/bria.2002.14.1.247

L. \& Tyler (2008), "Behavioral effects of nonfinancial performance measures: The role of procedural fairness," Behav. Res. Account., vol. 20, no. 2, pp. 55-71. Retrieved from https://doi.org/10.2308/bria.2008.20.2.55

L. Kren (1992), "Budgetary participation and managerial performance: The impact of information and environmental volatility," Account. Rev., pp. 511-526.

Lau and Buckland (1988), "The effect of participative budgeting on job satisfaction and performance: Role ambiguity as an intervening variable," Accounting, Organ. Soc., vol. 13, no. 3, pp. 225-233. Retrieved from https://doi.org/10.1016/0361-3682(88)90001-3

M. I. Goran, K. D. Reynolds, and C. H. Lindquist (1999), "Role of physical activity in the prevention of obesity in children," Int. J. Obes., vol. 23, no. 3, pp. S18-S33. Retrieved from https://doi.org/10.1038/sj.ijo.0800880

M. S. P. Hasibuan and H. M. S. P. Hasibuan (2016), Manajemen sumber daya manusia. Bumi Aksara.

M. Zayas-Ortiz, E. Rosario, E. Marquez, and P. C. Gruñeiro (2015), "Relationship between organizational commitments and organizational citizenship behaviour in a sample of private banking employees," Int. J. Sociol. Soc. Policy. Retrieved from https://doi.org/10.1108/IJSSP-02-2014-0010

N. Kock (2011), "Using WarpPLS in e-collaboration studies: Mediating effects, control and second order variables, and algorithm choices," Int. J. eCollaboration, vol. 7 , no. 3, pp. 1-13. Retrieved from https://doi.org/10.4018/jec.2011070101 
P. C. Earley and E. A. Lind (1987), "Procedural justice and participation in task selection: The role of control in mediating justice judgments.," J. Pers. Soc. Psychol., vol. 52, no. 6, p. 1148. Retrieved from https://doi.org/10.1037/0022-3514.52.6.1148

S. D. Pearson and L. H. Raeke (2000), "Patients' trust in physicians: many theories, few measures, and little data," J. Gen. Intern. Med., vol. 15, no. 7, pp. 509-513. Retrieved from https://doi.org/10.1046/j.1525-1497.2000.11002.x

S. P. Robbins (2003), "Perilaku Organisasi. Edisi Sembilan. Jakarta: PT. Indeks," J. "Acta Diurna, vol. 3, no. 4.

S. Sugiarti, E. Widyastuti, E. M. Sutanto, and A. Yulandari (2021), "Analisis Faktor yang Mempengaruhi Penerapan Kode Etik Pegawai di BPPKAD Kota Surakarta," J. Akunt. dan Pajak, vol. 22, no. 1.

T. and Walker (1989), "Effects of procedural and distributive justice on reactions to pay raise decisions," Acad. Manag. J., vol. 32, no. 1, pp. 115-130. Retrieved from https://doi.org/10.5465/256422

Y. G. Habba, M. Capochichi-Gnambodoe, and Y. Leprince-Wang (2017), "Enhanced photocatalytic activity of iron-doped $\mathrm{ZnO}$ nanowires for water purification," Appl. Sci., vol. 7, no. 11, p. 1185. Retrieved from https://doi.org/10.3390/app7111185

Y. Kusumawardani, L. Sulistyowati, and A. Cholil (2015), "Potensi antagonis jamur endofit pada tanaman lada (Piper nigrum L.) terhadap jamur Phytophthora capsici Leionian penyebab penyakit busuk pangkal batang," J. Hama dan Penyakit Tumbuh., vol. 3, no. 1, p. pp-21. 